\title{
Effectiveness of Turmeric Ethanol Extract Cream Preparation (Curcuma Longa) in Speeding up Wound Healing in Male Wistar Rats
}

\author{
Wang Ling ${ }^{1}$, Florenly ${ }^{2}$ Liena $^{3}$, Dewi Riastawaty Purba ${ }^{4}$ \\ ${ }^{1,2,3.4}$ Departement of Medicine, Faculty of Medicine, University of Prima Indonesia \\ ly@unprimdn.ac.id
}

\begin{abstract}
Injury is the loss or damage of some body tissues, due to a factor that interferes with the body's protective system. The results of several studies state turmeric rhizome extract is effective in wound healing. This study aims to find out the effect of turmeric extract (Curcuma longa) on wound healing in white rats. This type of research is experimental with the approach of Pre-test and Post-test group only control design, conducted November to December 2020. The samples used were turmeric rhizomes (Curcuma Longa) and male white rats. Determination of the size of the sample according to Federer's formula, so that the number of samples as many as 25 mice, the division of 4 treatment groups and 1 control group. The results of the study from the Anova test obtained a Sig value. Calculate 0.000 while sig value $(\alpha)$ is 0.05 which means sig value. Count sig $<(\alpha)$. This means that there is a real influence of the administration of turmeric extract (Curcuma Longa) on the healing of sores in mice. Turmeric ethanol extract (Curcuma Longa) has several bioactive compounds such as alkaloids, flavonoids, saponins, and tannins that play a role in wound healing. The optimum concentration of turmeric ethanol extract (Curcuma Longa) that can cure sores in white rats is 5\%. The highest percentage of cures on $k-14$ days was in the positive control (Bioplacenton $\circledR$ ) which was $95 \%$ and followed by extract 5\% v/ $v$ with a cure percentage of 90\%. The creamy preparation of turmeric ethanol extract (Curcuma Longa) has an ability that is close to Bioplacenton ${ }^{\circledR}$ in healing wounds in mice.
\end{abstract}

Keywords: curcuma longa; ethanol; wound

\section{Introduction}

Injuries are cases of injury that are often experienced by every human being. Wounds are the loss or damage of some body tissues (Suarni and Prameswarie, 2015), because of a factor that interferes with the body's protective system. Several factors that cause injuries such as bites, accidents, sharp objects, bullet shots, and metal objects (Afandi, 2017). The shape of the wound differs depending on the cause, some are open and closed. One example of an open wound is an incision where there is a linear tear in the skin and tissue underneath. The Ministry of Health's Basic Health Research data released in 2013 stated the number of causes of unintentional injuries such as falling from motorcycles, sharp objects/blunts, land transportation and falls with a prevalence rate of 0.7 percent of the Indonesian population ('RISKESDAS', 2013).

The healing phase is various in several phases, namely the inflammatory phase, proliferative phase, and maturation phase. The inflammatory phase is characterized by hemostasis, chemotaxis, and increased permeability of blood vessels that limit further damage, close wounds, remove cellular debris and bacteria and encourage cellular migration. The duration of the inflammatory stage usually lasts several days (Wissen et al., 2020). The proliferative phase is characterized by the formation of granulation tissues, recapitalization, and neovascularization. This phase can last several weeks. The maturation and remodeling phase is where the wound reaches maximum strength at maturity (Kartika 
et al., 2015); (Hernawati, 2015); (Hardhani, Lastianny and Herawati, 2014). Wound healing is the body's attempt to restore its structural integrity and normal function after disruption of tissues (Johnston, 2017). The wound healing process can be divided into three main phases namely, the inflammatory phase, the proliferation phase, and the remodeling phase (Novyana and Susanti, 2016).

Of the many varieties of plants in Indonesia that can be developed into traditional medicine, one of them is the turmeric plant (Curcuma longa Linn). Turmeric (Curcuma longa Linn or Curcuma domestica Val) including the family Zingiberaceae, has long been known by the public as a plant that has many benefits such as anti-inflammatory, anticancer, antioxidant, antiulcus, and antibacterial (Purwaningsih, 2016). According to research Wientarsih et al (2012) known turmeric rhizome extract is effective in wound healing (Wientarsih, Winarsih and Sutardi, 2012). Supported by research Yunianto et al (2017), From the results of his research on the test of ointment activity with the active ingredient turmeric that in vitro and in vivo, turmeric is antimicrobial that can kill and inhibit the growth of several types of fungi, bacteria and viruses (Yunianto, Lestari and Winarso, 2017). This study aims to find out the effect of turmeric extract (Curcuma longa) on wound healing in white rats.

\section{Review of Literature}

Turmeric (Curcuma longa Linn) has several pharmacological properties, including anti-inflammatory action (Manarin et al., 2019); (Setiadi, Khumaida and Wahyuning Ardie, 2017); (Kocaadam and Şanlier, 2017), anticancer (Roihatul Mutiah, 2015), antioxidant (Roihatul Mutiah, 2015); (Abdul-Aziz, 2011), and antibacterial. The content of flavonoids in Curcuma longa, as an immunostimulant substance, then the production of growth hormones such as EGF, TGF $\alpha$, PDGF, VEGF, FGF, and TGF $\beta$ will also increase, so that wound healing can be accelerated (Ayati et al., 2019). Berdasarkan klasifikasi mechanism of injury maka luka terbagi atas, luka iris, luka memar, luka terkoyak, luka bocor, luka gores (Achfidawati, Elfiah and Sakinah, 2019).

\section{Research Methods}

This type of research is experimental with the approach of Pre-test and Post-test group only control design, conducted November to December 2020. The samples used were turmeric rhizomes (Curcuma Longa) and male white rats. Determination of the size of the sample according to Frederer's formula, so that the number of samples as many as 25 mice, the division of 4 treatment groups and 1 control group.

\subsection{Material}

The ingredients used are alcohol, aluminum foil, aquadest, Turmeric (Curcuma Longa), 96\% ethanol, rat test animals (mus musculus), sterile gauze, whatman filter paper, methyl paraben, petroleum ether, plaster, propylene glycol, gloves, triethanolamine.

\subsection{Tool}

Tools used include glass tools (pyrex ${ }^{\circledR}$ ), autoclaves, maceration vessels, blenders (Maspion ${ }^{\circledR}$ ), porcelain cups, funnel lengths (Tricle brand $\AA$ ), ovens, tweezers, rotavapor (Heidolf®), iron spoons, analytical scales (Precisa $\left.{ }^{\circledR}\right)$, and water baths. 


\subsection{Research Procedure}

Turmeric (Curcuma Longa) which has been identified washed thoroughly with running water, then lined and then spread on paper until the water is absorbed, after which the turmeric sample (Curcuma Longa) is weighed. Then the material is dried, mashed until it becomes powder and forms simplisia (Kosasih et al., 2019)

\subsection{Cream Preparations}

Table 1. Making Turmeric Rhizome Ethanol Extract Cream (Curcuma longa)

\begin{tabular}{llcccc}
\hline \multirow{2}{*}{ No } & \multicolumn{1}{c}{ Material } & \multicolumn{2}{c}{ Formula / concentration (\%, v/v) } \\
\cline { 2 - 6 } & & I & II & III & IV \\
\hline 1 & Turmeric Rhizome Ethanol Extract & 1 & 3 & 5 & 7 \\
\hline 2 & Setil alcohol & 3 & 3 & 3 & 3 \\
\hline 3 & Stearic acid & 5 & 5 & 5 & 5 \\
\hline 4 & Gliserin $(\mathrm{ml})$ & 15 & 15 & 15 & 15 \\
\hline 5 & Parafin & 5 & 5 & 5 & 5 \\
\hline 6 & Adeps lanae & 5 & 5 & 5 & 5 \\
\hline 7 & Span 60 & 2 & 2 & 2 & 2 \\
\hline 8 & Tween 60 & 2 & 2 & 2 & 2 \\
\hline 9 & Metil paraben & 0,1 & 0,1 & 0,1 & 0,1 \\
\hline 10 & Propil paraben & 0,05 & 0,05 & 0,05 & 0,05 \\
\hline 11 & Vitamin E & 0,05 & 0,05 & 0,05 & 0,05 \\
\hline 12 & Distilled water & 57,8 & 57,6 & 55,8 & 55,6 \\
\hline
\end{tabular}

\subsection{Test Animal Setup}

A total of 25 mice were divided into 5 groups, each group consisted of, group I was given standard feed and given a $1 \%$ turmeric ethanol extract cream preparation (Curcuma Longa) as much as $1 \mathrm{~g}$ applied once every 24 hours. Group II was given a standard feed and given a $3 \%$ turmeric ethanol extract cream (Curcuma Longa) dosage of 1 gr applied once every 24 hours. Group III was given a standard feed and given a 5\% 5\% turmeric ethanol extract cream (Curcuma Longa) as much as $1 \mathrm{~g}$ applied once every 24 hours. Group IV was given standard feed and given a $7 \%$ turmeric ethanol extract cream (Curcuma Longa) of $1 \mathrm{~g}$ applied once every 24 hours. Group V positive control, fed standard and applied $1 \mathrm{~g}$ Bioplacenton ${ }^{\circledR}$ once every 24 hours. Inclusion criteria include: white mice, male sex, age 6 - 8 weeks, weight $150-200 \mathrm{~g}$, and healthy as long as the mice are given a cut on the back area along $2 \mathrm{~cm}$. Exclusion criteria include: mice sick during the adaptation period, sick during treatment, die during treatment.

\subsection{Wound-giving}

Animals try dianastesi using ether liquid, then shaved rat feathers sufficiently on the back area. Each rat is given an incision on its back using a sterile scalpel, $2 \mathrm{~cm}$ long with a depth of $1 \mathrm{~mm}$ from the surface of the skin of the white rat's back.

\subsection{Antioxidant Test}

The method used is a reduction in the concentration of diphenilpicrylhydrazil (DPPH). The parameter used is EC50 (the concentration of extract in reducing 50\% DPPH) (Molyneux, 2004). Sample capture of DPPH is measured by UV-vis at a wavelength of $517 \mathrm{~nm}$. 


\subsection{Data Analysis}

Data processing techniques are carried out from observations in terms of changes that occur in wounds and changes in the size of wounds in areas that have been treated. Then analyzed the normality of the data and continued with the ANOVA test.

\section{Discussion}

\subsection{Phytochemical Screening}

Table 2. Turmeric Phytochemical Screening (Curcuma Longa)

\begin{tabular}{llc}
\hline \multicolumn{1}{c}{ Test } & \multicolumn{1}{c}{ Result } & Information \\
\hline \multirow{3}{*}{ Alkaloid } & Brown red deposits & $(+)$ \\
\cline { 2 - 3 } & White precipitate & $(+)$ \\
\cline { 2 - 3 } & Chocolate deposits & $(+)$ \\
\hline Flavonoid & Red color on the layer of amyl alcohol & $(+)$ \\
\hline Saponin & Permanent foam & $(+)$ \\
\hline Tanin & Blackish green color & $(+)$ \\
\hline
\end{tabular}

From table 2 it is known that turmeric extract (Curcuma Longa) contains chemical compounds alkaloids, flavonoids, saponins, and tannins. In the alkaloid test, brown-red deposits were found for the Dragendorff reagent, white deposits resulting from the addition of Mayer reagents, and brown deposits for the Borchardt test. In flavonoid tests according to the library is said to be positive when forming yellow, orange, and red colors (Baud, Sangi and Koleangan, 2014). For the saponin test from the test results, it is known that turmeric extract (Curcuma Longa) positively contains saponins because of the formation of a permanent foam. Tannin testing also showed positive results because the results of testing turmeric extract (Curcuma Longa) formed a blackish green color (Baud, Sangi and Koleangan, 2014). According to Soni \& Singhai (2012), Tannin compounds can act as astringents in wounds while saponins work to increase epithelial speed. Flavonoid compounds also play a role in wound healing by stopping bleeding through vasocontress mechanisms in blood vessels, free radical antidotes, hydrolysis inhibitors, and enzyme oxidation, and anti-inflammatory (Soni and Singhai, 2012).

\subsection{Anti-oxidant Testing}

Antioxidant testing is performed using the UV-Vis spectrometry method at a wavelength of $517 \mathrm{~nm}$ with 2-2-Diphenyl-1-picrylhydrazil (DPPH). The results of antioxidant testing of turmeric extract (Curcuma Longa) can be seen at the following table:

Table 3. Percentage Data of Inhibition of Turmeric Extract (Curcuma Longa) against DPPH

\begin{tabular}{llll}
\hline Extract Concentration (ppm) & $\begin{array}{l}\text { Absorbance } \\
\text { Extract }\end{array}$ & $\begin{array}{l}\text { Absorbance } \\
\text { Control }\end{array}$ & Inhibition (\%) \\
\hline 3 & 0.223 & 0,529 & 57.73 \\
\hline 5 & 0.219 & 0,529 & 58.48 \\
\hline 7 & 0.217 & 0,529 & 58.86 \\
\hline 9 & 0.164 & 0,529 & 68.86 \\
\hline
\end{tabular}

Based on table 3, it is seen that the absorption of DPPH by turmeric extract (Curcuma Longa) shows a decrease as the concentration of the extract increases. The 
diamond value of the extract also increased with the increase in the concentration of extracts with the largest inhibition value being 68.86\% at a concentration of $9 \mathrm{ppm}$. Research results (Suhendra, 2017), Entitled antioxidant activity of turmeric powder extract, from the results of the study, found that antioxidant activity with a difference in concentrations of $0 \%, 10 \%, 30 \%, 50 \%, 70 \%$, and $90 \%$. Turmeric extract has a yield of $7.82 \%$, a total amount of phenols of $2.82 \%$, antiradical activity DPPH $1.13 \%$, and has high activity in inhibiting the fat oxidation process. The greater the absorbance in TBA (thiobarbituric acid) testing, the smaller the antioxidant activity supplemented in linoleic acid. Based on the six charts below shows the addition of turmeric extract can inhibit the formation of MDA malonaldehyde acid (MDA). This is seen from the comparison of control.

\subsection{Effectiveness of Turmeric Extract Against Sores}

The healing process of wounds with the administration of a gel containing turmeric extract (Curcuma Longa) can be seen below (Figure 1):

\section{a. Effectiveness of Turmeric Extract against Sores}

The healing process of wounds with the administration of a gel containing turmeric extract (Curcuma Longa) can be seen below (Figure 1):

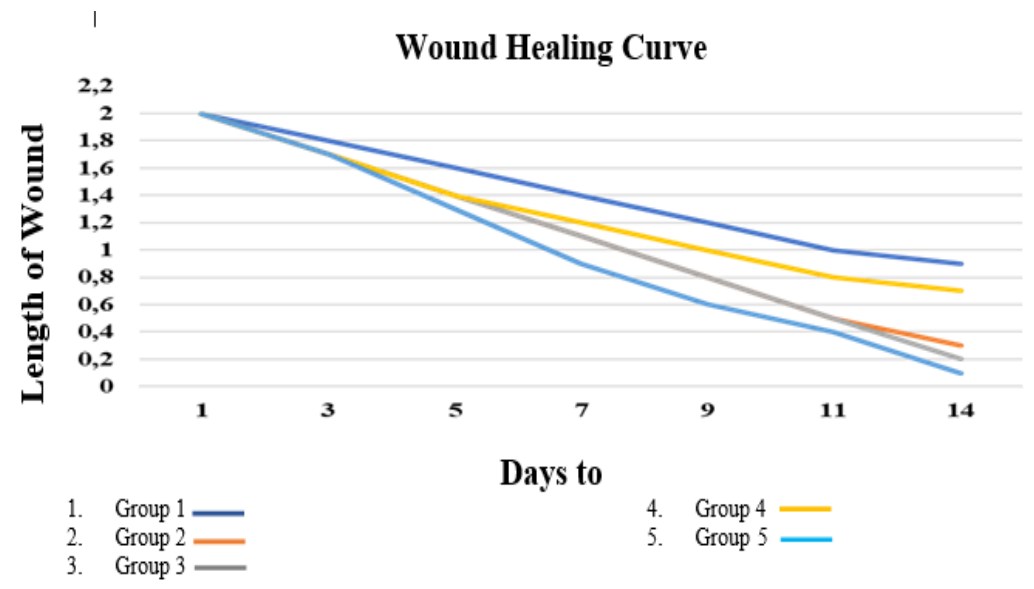

Figure 1. Wound Length Reduction Graph

The graph above describes the healing of wounds with variations in the concentration of turmeric extract (Curcuma longa). $1 \% \mathrm{v} / \mathrm{v}, 3 \% \mathrm{v} / \mathrm{v}, 5 \% \mathrm{v} / \mathrm{v}, 7 \% \mathrm{v} / \mathrm{v}$, and Bioplacenton positive control ${ }^{\circledR}$ consecutively. Based on the graph, it can be seen that mice with bioplacenton treatment ${ }^{\circledR}$ have a high cure rate compared to other groups. The $3 \% \mathrm{v} / \mathrm{v}$ concentration of the extract and the $5 \% \mathrm{v} / \mathrm{v}$ concentration of the extract had the same cure rate, only slightly different on the last day of measurement (day 14). This may be affected by the concentration of the extract at a smaller $3 \%$ concentration. However, at a concentration of $7 \% \mathrm{v} / \mathrm{v}$ extract, the wound recovery rate was much less than the previous two concentrations of the extract, where the concentration was smaller. The lowest cure rate in treatment with $1 \% \mathrm{v} / \mathrm{v}$ extract with wound length on the 14 th day is $0.9 \mathrm{~cm}$. Based on these results it can be seen that the optimum concentration of turmeric extract (Curcuma Longa). It is at $5 \% \mathrm{v} / \mathrm{v}$ with a wound that remains $0.2 \mathrm{~cm}$ long. For more details, you can see the following table: 
Table 4. Changes in Wound Length with Varying Concentrations of Extracts

\begin{tabular}{cccccc}
\hline \multirow{2}{*}{ Day To } & \multicolumn{5}{c}{ Changes in wound length (cm) } \\
\cline { 2 - 6 } & $\begin{array}{c}\text { Concentration } \\
\mathbf{1 \%}\end{array}$ & $\begin{array}{c}\text { Concentration } \\
\mathbf{3 \%}\end{array}$ & $\begin{array}{c}\text { Concentration } \\
\mathbf{5 \%}\end{array}$ & $\begin{array}{c}\text { Concentration } \\
\mathbf{7 \%}\end{array}$ & Bioplacenton \\
\hline 1 & 2 & 2 & 2 & 2 & 2 \\
\hline 3 & 1.8 & 1.7 & 1.7 & 1.7 & 1.7 \\
\hline 5 & 1.6 & 1.4 & 1.4 & 1.4 & 1.3 \\
\hline 7 & 1.4 & 1.1 & 1.1 & 1.2 & 0.9 \\
\hline 9 & 1.2 & 0.8 & 0.8 & 1 & 0.6 \\
\hline 11 & 1 & 0.5 & 0.5 & 0.8 & 0.4 \\
\hline 14 & 0.9 & 0.3 & 0.2 & 0.7 & 0.1 \\
\hline
\end{tabular}

Based on table 4, it can be seen that Bioplacenton ${ }^{\circledR}$ as a positive control experiencing faster wound healing. The length of the wound on the 3rd day has experienced a reduction in the length of the wound and on the 14th day, the incision wound given bioplacenton ${ }^{\circledR}$ has had the largest percentage of cures. This is because the composition of Bioplacenton ${ }^{\circledR}$ has the active ingredients of placental extract and neomicin sulfate which is efficacious to trigger the formation of new tissue and prevent infection in the wound area (Fitria, Arifin and Kurniasih, 2017). When viewed from the rate of wound healing per day, on the 1 st to 7 th day the wound healing rate is still linear, but on the 9 th to the 14th day there is a decrease in the cure rate at a concentration of $7 \%$ compared to treatment at a concentration of $5 \%$ and far behind when compared to those given Bioplacenton ${ }^{\circledR}$. When compared, the length of the wound on the treatment of a concentration of 5\% turmeric extract (Curcuma Longa) only differed by $0.1 \mathrm{~cm}$ with Bioplacenton ${ }^{\circledR}$ on the 14th day. It can be concluded that turmeric (Curcuma Longa) has the ability to heal wounds, although the speed of healing is not as fast as Bioplacenton ${ }^{\circledR}$ when viewed from the reduction of wound length from day to day. The ability to heal these wounds may be influenced by the content of compounds present in the extract such as flavonoids, alkaloids, saponins, and tannins.

Previously (Milasari, 2019), With the title of the study the effect of giving yellow turmeric extract ointment (curcuma longa linn) on wound healing in white mice (rattus norvegicus), stated that the administration of yellow turmeric extract ointment concentrations of $10 \%, 20 \%$ and $30 \%$ affects the speed of wound healing in treatment rats and based on observation of anatomical pathology and post hoc tests with LSD showed that the ointment of yellow turmeric extract $10 \%$ is the best preparation in the wound healing process. Where the significant differences of each group are evident on day 7.

According to research (Indah and Br, 2019), Based on the results of the study, it can be concluded that turmeric rhizome extract ointment (Curcuma domestica Val.) at a dose of $8 \%$ can be used as a wound medicine but is less effective when compared to the drug povidone iodine. The physiological process of wound healing can be divided into four phases, namely the inflammatory phase, the destructive phase, the proliferative phase, and the maturation phase. The inflammatory phase lasts from the start of the wound until approximately the 3rd day (Purnama, Sriwidodo and Ratnawulan, 2017). The first thing that happens after a wound is the eratization of platelets. Blood vessels that are damaged at the time of the injury will cause bleeding and the body will stop it with vasocontance, dredining of the ends of damaged blood vessels, and hemostasis reactions (Pebri, Rinidar and Amiruddin, 2017). 
The next healing phase is the destructive phase which is the cleansing phase against dead tissues as well as bacteria by polymorphs and macrophages. This phase lasts around day 2 to day 5 after the injury occurs (Sentat and Permatasari, 2015). These cells are not only able to destroy bacteria and secrete tissues that are deviational and excessive fibrin, but are able to stimulate the formation of fibroblasts that synthesize the structure of collagen proteins and produce a factor that can stimulate angiogenesis. Healing stops when macrophages deactivate, but the healing process continues despite large reductions in polymorphs (Sentat and Permatasari, 2015).

The next phase of wound healing is the proliferation phase called the fibroplasia phase because in this phase the process of proliferation of fibroblast cells is very prominent (Sentat and Permatasari, 2015; Pebri, Rinidar and Amiruddin, 2017). In the proliferation phase, wounds are filled with inflammatory cells, fibroblasts, and collagen. In this phase there is also the formation of new blood vessels (angiogenesis), forming reddish-colored tissue with a smoothly lined surface called granulation tissue (Purnama, Sriwidodo and Ratnawulan, 2017). The wound edge epithelium consisting of basal cells detaches from its base and moves to fill the surface of the wound, while the place is filled by new cells formed from the mitosis process. The process of fibroplasia and granulation tissue formation stops when the entire epithelium touches each other and closes the surface of the wound, after which the maturation process begins in the maturation or remodeling phase (Hernawati, 2015).

The last phase of wound healing is the epithelial maturation phase, contraction, and reorganization of connective tissue occur in this phase. The maturation phase takes place after the proliferation phase ends, around the 14th day, and can be up to 365 days after the injury occurs and is declared over when all signs of inflammation have disappeared (Sintesis and Pada, 2020). In this phase the body tries to restore everything that becomes abnormal when the wound healing process becomes normal. Edem and inflammatory cells are absorbed, young cells mature, new capillaries close and reabsorbed, excess collagen is absorbed and the rest constricts according to the magnitude of the strain (Wientarsih, Winarsih and Sutardi, 2012). During this process, scar tissue is produced that is pale, thin, supple, and easily moved from the base. Seen maximum dredification in the wound and at the end of this phase the wound is able to withstand strain up to $80 \%$ of normal skin ability. Secondary metabolite compounds contained in turmeric extract (Curcuma Longa) have bioactive properties such as flavonoids that play a role in the inflammatory process. During the occurrence of wounds on the skin of mice, flavonoids play a role in inhibiting the formation of prostaglandins and other inflammatory mediators such as leukotriene. Inhibition of the production of both compounds accelerates the inflammatory process to the next process, namely proliferation (Anwar et al., 2018). Furthermore, in the proliferation phase, saponins act as anti-fungal and anti-microbial (Sugiaman, 2011), which can increase the number of macrophages in the wound area.

Increased macrophages affect increased secretion of growth factors, the number of fibroblasts migrating to the wound area, and collagen synthesis. This of course accelerates the process of wound proliferation (Putri, 2020). In addition, tannins also play a role in wound healing by increasing the re-formation of dermis tissue in wound tissue (fibroplasia) (kurnianto). In addition, the alkaloids contained in turmeric extract (Curcuma Longa) can inhibit bacterial growth by interfering with peptidoglycans in bacterial cells that cause the formation of cell walls (Kumara, Sri Pradnyani and Sidiarta, 2019); (Pangemanan, . and Budiarso, 2016). 


\section{b. Data Analysis}

Results from the normality test in table 4. It uses the Kolmogorov-Smirnov method which shows an Absolute value of 0.090. The kolmogorov table value for the sample number 140 is 0.115 , then $0.90<0.115$ or the kolmogorov value calculates < of the kolmogorov table value. This means the wound recovery data for the extract is normal distribution. This is also evidenced by the results of the probability test on SPSS i.e. look at the value of Asymp. Sig. ( 2 tailed) the value is 0.207 where the $>0.05$ which means the normal distribution data. For the treatment of positive controls (Bioplacenton ${ }^{\circledR}$ ), the calculated kolmogorov value is 0.108 with $\mathrm{N}=25$. The table data with $\mathrm{N}=25$ is 0.224 , then $0.109<0.224$. Data Asymp. Sig. ( 2 tailed) shows a value of 0.800 which means data for wound healing using Bioplacenton ${ }^{\circledR}$ normal distribution, this means the entire normal distributed data.

Table 5. Kolmogorov-Smirnov Normality Test Results

\begin{tabular}{|c|c|c|c|}
\hline & & $\begin{array}{c}\text { Wound Healing } \\
\text { (Extract) }\end{array}$ & $\begin{array}{c}\text { Wound Healing } \\
\text { (Bioplacenton } \AA)\end{array}$ \\
\hline $\mathrm{N}$ & & 140 & 25 \\
\hline \multirow{2}{*}{ Normal Parameters ${ }^{\mathrm{a}, \mathrm{b}}$} & Mean & 1.0970 & 1.0285 \\
\hline & Std. Deviation & .56998 & .63318 \\
\hline \multirow{3}{*}{$\begin{array}{l}\text { Most } \\
\text { Differences }\end{array}$} & Absolute & .090 & .109 \\
\hline & Positive & .090 & .098 \\
\hline & Negative & -.089 & -.108 \\
\hline Kolmogorov-Smirnov Z & & 1.063 & .644 \\
\hline Asymp. Sig. (2-tailed) & & .207 & .800 \\
\hline
\end{tabular}

Effectiveness of the entire concentration of turmeric extract (Curcuma Longa). The healing of wounds can be seen by analysis of variance (ANOVA) or variance analysis (ANAVA). The ANOVA test conducted is a significance test to see the difference in giving turmeric extract (Curcuma Longa) to wound healing. The results of the test can be seen in the following table:

Table 6. Test Results of the Effect of Extracts on Healing of Cuts ANOVA

\begin{tabular}{|c|c|c|c|c|c|c|}
\hline & & $\begin{array}{l}\text { Sum of } \\
\text { Squares }\end{array}$ & df & $\begin{array}{c}\text { Mean } \\
\text { Square } \\
\end{array}$ & $\mathbf{F}$ & Sig. \\
\hline \multirow[t]{3}{*}{ Ekstrak Kunyit } & Between Groups & 6.843 & 3 & 2.281 & 8.095 & .000 \\
\hline & Within Groups & 38.316 & 136 & .282 & & \\
\hline & Total & 45.159 & 139 & & & \\
\hline
\end{tabular}

Table 6. shows the value $F_{\text {count }}$ as much as 8,095. To find a value in the Value Table $\mathrm{F}$ for $\mathrm{df}=3 / 136$ with probability $(\alpha) 0,05$ acquired value $\mathrm{F}_{\text {table }}$ as much as 2,67 . So that the value $F_{\text {count }}>F_{\text {table }}$ this means that overall there is a real influence on the administration of turmeric extract (Curcuma Longa) on the healing of wounds. To confirm this hypothesis test, it can be seen in the sig value. Calculate 0.000 while sig value $(\alpha)$ is 0.05 which means sig value. Count sig $<(\alpha)$. This means that there is a real influence of the administration of turmeric extract (Curcuma Longa) on the healing of wounds in mice. 


\section{c. Bioplacenton Effectiveness ${ }^{\circledR}$ On Wound Healing}

The effect or effectiveness of Bioplacenton ${ }^{\circledR}$ on wound healing can be reviewed with the Anova test. The results of the test can be seen in the following table:

Table 7. Results of Bioplacenton ${ }^{\circledR}$ (positive control) Effect Test on Wound Length

\begin{tabular}{lccccc}
\hline \multicolumn{7}{c}{ ANOVA } & & & \\
\hline & $\begin{array}{c}\text { Sum of } \\
\text { Squares }\end{array}$ & Df & Mean Square & F & Sig. \\
\hline Between Groups & 11.927 & 6 & 1.987 & 32.654 & .000 \\
\hline Within Groups & 1.704 & 28 & .061 & & \\
\hline Total & 13.631 & 34 & & & \\
\hline
\end{tabular}

Based on table 7. It can be seen that the value $F_{\text {count }}$ is 32,654 while the value $F_{\text {table }}$ is 2,45 yang berarti $F_{\text {count }}>F_{\text {table. }}$. When viewed the sigifiance value, the signinifikan value of the count is 0.000 which is smaller than the alpha value of 0.05 or $p<0.05$. From this data it can be concluded that there is a real influence in the provision of Bioplacenton ${ }^{\circledR}$ on the healing of wounds. The wound healing process becomes important because the skin is a single organ that is exposed to the outside world. The skin has specific functions for the body, namely protective, sensory, thermoegulatoric, metabolic, and sexual signals. When the skin loses its continuity, those functions cannot run as they should (Ramadhian et al., 2017). Therefore, the wound healing process requires proper management and treatment so that the wound area does not become infected and ultimately cause chronic wounds (Aminuddin, et.al., 2020).

Wound healing is a complex biological process that results in the recovery of integrity tissues. Physiologically, the wound healing process can be divided into four glutting values of hemostasis, inflammation, proliferation and tissue rermulelling. Many factors are known to slow wound healing, namely malnutrition, hypoxia. Immunosuppression, chronic diseases and post-surgical conditions. It is very important for the surgeon to understand the physiological processes involved in wound healing to maximize the patient's morbidity from the delayed wound healing process (Phillips, 2000); (Young and McNaught, 2011).

\section{Conclusion}

Based on the results of research and analysis of data on the effectiveness of giving turmeric ethanol extract (Curcuma Longa) and Bioplacenton ${ }^{\circledR}$ against wound healing in white rats it can be concluded that turmeric ethanol extract (Curcuma Longa) has several bioactive compounds such as alkaloids, flavonoids, saponins, and tannins that play a role in wound healing. The optimum concentration of turmeric ethanol extract (Curcuma Longa) that can cure sores in white rats is $5 \%$. The highest percentage of cures on k-14 day was in positive control (Bioplacenton ${ }^{\circledR}$ ) which was $95 \%$ and followed by extract $5 \% \mathrm{v} / \mathrm{v}$ with a cure percentage of $90 \%$. Turmeric ethanol extract cream preparations (Curcuma Longa) have the ability to approach Bioplacenton ${ }^{\circledR}$ in healing wounds in mice.

\section{References}

Abdul-Aziz, K. K. (2011) 'Comparative Evaluation of the Anti-ulcer Activity of Curcumin and Omeprazole during the Acute Phase of Gastric Ulcer-Efficacy of Curcumin in Gastric Ulcer Prevention against Omeprazole', Food and Nutrition Sciences, 02(06), 
pp. 628-640. doi: 10.4236/fns.2011.26088.

Achfidawati, H. N., Elfiah, U. and Sakinah, E. N. (2019) 'Analysis of Morphology and Erythrocyte Count in Rat after Electrical Exposure', Journal of Agromedicine and Medical Sciences, 5(1), p. 25. doi: 10.19184/ams.v5i1.6806.

Afandi, D. (2017) Tata Laksana dan Teknik Pembuatan Visum et Repertum, University of Riau Press.

Aminuddin, et.al., 2020 (2020) Modul Perawatan luka.

Anwar, K. et al. (2018) 'Wound Healing Activity of Ethanolic Extract Gel of Tawas Ut Tuber (Ampelocissus rubiginosa L.) in Incisional Model Wistar Rats', Majalah Obat Tradisional, 23(1), p. 30. doi: 10.22146/mot.29063.

Ayati, Z. et al. (2019) 'Ethnobotany, Phytochemistry and Traditional Uses of Curcuma spp. and Pharmacological Profile of Two Important Species (C. longa and C. zedoaria): A Review', Current Pharmaceutical Design, 25(8), pp. 871-935. doi: 10.2174/1381612825666190402163940.

Baud, G. S., Sangi, M. S. and Koleangan, H. S. J. (2014) 'Analisis Senyawa Metabolit Sekunder dan Uji Toksisitas Ekstrak Etanol Batang Tanaman Patah Tulang (Euphorbia Tirucalli L.) dengan Metode Brine Shrimp Lethality Test (BSLT)', Jurnal Ilmiah Sains, 14(2), p. 106. doi: 10.35799/jis.14.2.2014.6065.

Fitria, V., Arifin, R. F. and Kurniasih, N. (2017) 'Uji aktivitas gel ekstrak daun pohpohan (Pilea trinervia W.) terhadap penyembuhan luka bakar pada kelinci (Oryctolagus cuniculus)', Kartika : Jurnal Ilmiah Farmasi, 5(2), p. 75. doi: 10.26874/kjif.v5i2.120.

Hardhani, P. R., Lastianny, S. P. and Herawati, D. (2014) 'Pengaruh Penambahan Platelet Rich Plasma Pada Bovine Porous Bone Mineral Terhadap Penyembuhan Jaringan PHardhani, P. R., Lastianny, S. P., \& Herawati, D. (2014). Pengaruh Penambahan Platelet Rich Plasma Pada Bovine Porous Bone Mineral Terhadap Penyembuhan', Journal Kedokteran Gigi, 5(4), pp. 342-48. Available at: https://journal.ugm.ac.id/jkg/article/download/29330/17505.

Hernawati, S. (2015) 'Ekstrak Buah Delima sebagai Alternatif Terapi Recurrent Apthous Stomatitis (RAS)', Stomatognatic, 12(1), pp. 20-25.

Indah, S. and Br, T. (2019) 'Uji Efektivitas Salep Ekstrak Rimpang Kunyit (Curcuma Domestica Val) untuk Pengobatan Luka Sayat pada Tikus Putih Jantan', Skripsi, Rogram Studi Sarjana Farmasi Fakultas Farmasi dan Kesehatan Institut Kesehatan Helvetia Medan.

Johnston, S., dan K. M. T. (2017) 'Veterinary Surgery: Small Animal Expert Consult', Elsevier. UK.

Kartika, R. W. et al. (2015) 'Perawatan Luka Kronis dengan Modern Dressing', Perawatan Luka Kronis Dengan Modern Dressing, 42(7), pp. 546-550.

Kocaadam, B. and Şanlier, N. (2017) 'Curcumin, an active component of turmeric (Curcuma longa), and its effects on health', Critical Reviews in Food Science and Nutrition, 57(13), pp. 2889-2895. doi: 10.1080/10408398.2015.1077195.

Kosasih, E. et al. (2019) 'Hepatoprotective Effect of Citrus Sinensis Peel Extract Against Isoniazid and Rifampicin-induced Liver Injury in Wistar Rats', Majalah Obat Tradisional, 24(3), pp. 197-203. doi: 10.22146/mot.45762.

Kumara, I. N. C., Sri Pradnyani, I. G. A. and Sidiarta, I. G. A. F. N. (2019) 'Uji efektivitas ekstrak kunyit (Curcuma longa) terhadap daya hambat pertumbuhan bakteri Streptococcus mutans', Intisari Sains Medis, 10(3), pp. 462-467. doi: 10.15562/ism.v10i3.350.

Manarin, G. et al. (2019) 'Curcuma longa L. ameliorates asthma control in children and adolescents: A randomized, double-blind, controlled trial', Journal of Ethnopharmacology, 238, p. 111882. doi: 10.1016/j.jep.2019.111882. 
Milasari, M. (2019) 'Pengaruh Pemberian Salep Ekstrak Kunyit Kuning (Curcuma Longa Linn) terhadap Penyembuhan Luka Sayat pada Tikus Putih (Rattus norvegicus)', Jurnal Ilmiah Ibnu Sina, 4(2), pp. 1-13.

Novyana, R. M. and Susanti (2016) 'Lidah Buaya (Aloe vera) untuk Penyembuhan Luka', Jurnal Kedokteran Universitas Lampung, 5, pp. 149-153.

Pangemanan, A., . F. and Budiarso, F. (2016) 'Uji daya hambat ekstrak rimpang kunyit (Curcuma longa) terhadap pertumbuhan bakteri Staphylococcus aureus dan Pseudomonas sp.', Jurnal e-Biomedik, 4(1). doi: 10.35790/ebm.4.1.2016.10840.

Pebri, I. G., Rinidar and Amiruddin (2017) 'Pengaruh Pemberian Ekstrak Daun Binahong (Anredera Cordifolia) terhadap Proses Penyembuhan Luka Insisi (Vulnus Incisivum) Pada Mencit (Mus Musculus)', Jurnal Ilmiah Mahasiswa Veteriner, 2(1), pp. 1-11. Available at: http://jurnal.stikesmukla.ac.id/index.php/cerata/article/view/130/128.

Phillips, S. J. (2000) 'Physiology of wound healing and surgical wound care', ASAIO Journal, 46(6), pp. 2-5. doi: 10.1097/00002480-200011000-00029.

Purnama, H., Sriwidodo and Ratnawulan, S. (2017) 'Review Sistematik: Proses Penyembuhan dan Perawatan Luka', Farmaka, 15(2), pp. 255-256.

Purwaningsih, E. (2016) 'Potensi Kurkumin Sebagai Bahan Anti Fertilitas', Jurnal Kedokteran Yarsi, 24(3), pp. 203-211.

Putri, G. A. (2020) 'Pada Penyembuhan Luka Soket Pasca Pencabutan Gigi Tikus Putih Galur Wistar (Rattus Novergicus) Secara Hematoxilin Eosin ( He ) Universitas Sumatera Utara Medan 2020'.

Ramadhian, R. M. et al. (2017) 'Pengaruh Ekstrak Metanol Daun Ketapang (Terminalia catappa L.) Terhadap Kepadatan Serabut Kolagen pada Penyembuhan Luka Sayat Mencit (Mus musculus)', J AgromedUnila|, 4(3), p. 17.

'Riskesdas' (2013) Badan Penelitian dan Pengembangan Kesehatan Kementerian Kesehatan RI, 7(5), pp. 803-809. doi: 10.1517/13543784.7.5.803.

Roihatul Mutiah (2015) 'Evidence Based Kurkumin dari Tanaman Kunyit (Curcuma Longa) sebagai Terapi Kanker Pada Pengobatan Modern', Jurnal Farma Sains, 1(1), pp. 28-41.

Sentat, T. and Permatasari, R. (2015) 'Uji Aktivitas Ekstrak Etanol Daun Alpukat ( Persea Americana Mill .) terhadap Penyembuhan Luka Bakar Pada Punggung', Jurnal Ilmiah Manuntung, 1(2), pp. 100-106.

Setiadi, A., Khumaida, N. and Wahyuning Ardie, D. S. (2017) 'Keragaman Beberapa Aksesi Temu Hitam (Curcuma aeruginosa Roxb.) Berdasarkan Karakter Morfologi', Jurnal Agronomi Indonesia (Indonesian Journal of Agronomy), 45(1), pp. 71-78. doi: 10.24831/jai.v45i1.13773.

Sintesis, T. and Pada, K. (2020) 'Jaringan Luka Tikus Putih Diabetik Effect of Channa lucius Extract on Collagen Synthesis in Wound Tissue of Diabetic Rats Skripsi Sarjana Sains oleh Siti Endang Mustika'.

Soni, H. and Singhai, A. K. (2012) 'a Recent Update of Botanicals for Wound Healing Activity', International Research Journal of Pharmacy, 3(7), pp. 1-7.

Suarni, E. and Prameswarie, T. (2015) 'Perbandingan Pemberian Gel Lidah Buaya (Aloe vera L.) dan Povidone Iodine terhadap Waktu Penyembuhan Luka Iris (Vulnus scissum) pada Mencit (Mus musculus) Galur Wistar', Syifa' MEDIKA: Jurnal Kedokteran dan Kesehatan, 5(2), p. 82. doi: 10.32502/sm.v5i2.1397.

Sugiaman, V. K. (2011) 'Peningkatan Penyembuhan Luka di Mukosa Oral Melalui Pemberian Aloe Vera (Linn.) Secara Topikal Topical', Maranatha Journal of Medicine and Health, 11(1), pp. 70-79.

Suhendra, L. (2017) 'Aktivitas antioksidan ekstrak bubuk kunyit (Curcuma domestica Val.)', Jurnal Ilmiah Teknologi Pertanian, 2(2), pp. 237-246. 
Wientarsih, I., Winarsih, W. and Sutardi, L. N. (2012) 'Aktivitas penyembuhan luka oleh gel fraksi etil asetat rimpang kunyit pada mencit hiperglikemik', Veteriner, 13(3), pp. 251-256.

Wissen, S. et al. (2020) 'Perbedaan Waktu Penutupan Luka Insisi yang Diaplikasikan Solutio Povidone Iodine $10 \%$ dengan Unguentum Kloramfenikol $2 \%$ pada Mencit Swiss Webster', 2(6), pp. 138-144. Available at: https://journal.maranatha.edu/index.php/jmh/article/view/2036.

Young, A. and McNaught, C. E. (2011) 'The physiology of wound healing', Surgery, 29(10), pp. 475-479. doi: 10.1016/j.mpsur.2011.06.011.

Yunianto, B., Lestari, T. and Winarso, A. (2017) 'Aktivitas Antibakteri Salep Dengan Bahan Aktif Ekstrak Kunyit, Kencur Dan Temugiring Terhadap Bakteri Staphylococcus Aureus', Jurnal Kebidanan dan Kesehatan Tradisional, 2(2), pp. 6065. doi: 10.37341/jkkt.v2i2.57. 